\title{
IMPACT OF WATER HYACINTH AND WATER LETTUCE AQUEOUS EXTRACTS ON GROWTH AND GERMINATION OF WHEAT AND ITS ASSOCIATED TROUBLESOME WEEDS
}

\author{
GUL, B..$^{1 *}$-SAEED, M. ${ }^{1}-$ KHAN, H. ${ }^{1}-$ KHAN, H. ${ }^{2}-$ KHAN, M. I. ${ }^{1}-$ KHAN, I. ${ }^{1}$ \\ ${ }^{I}$ Department of Weed Science The University of Agriculture \\ Peshawar, Pakistan \\ ${ }^{2}$ Department of Agronomy The University of Agriculture \\ Peshawar, Pakistan \\ *Corresponding author \\ e-mail: bakhtiargul@aup.edu.pk \\ (Received $18^{\text {th }}$ Oct 2016; accepted $1^{\text {st }}$ Mar 2017)
}

\begin{abstract}
To study the effect of Eichhornia crassipes and Pistia stratiotes on germination of wheat and its weeds, a lab experiment was laid out in Completely Randomized Design with 3 replications. The seeds of test species were soaked in respective concentrations of aquatic weeds' aqueous extracts for $24 \mathrm{hrs}$ before putting in Petri plates. E. crassipes extracts reduced wild oat germination to zero, milk thistle to $10 \%$ and wheat to $20 \%$. Similarly, P. stratiotes also reduced wild oat $(6.7 \%)$ and wheat germination (26.7\%). Shoot length is reduced to $2.57 \mathrm{~cm}$ in wild oat compared to milk thistle $(6.06 \mathrm{~cm})$ and wheat $(9.08 \mathrm{~cm})$. E. crassipes reduced wild oat shoot length weight to zero, while shoot weight of wheat is reduced $(0.06 \mathrm{~g})$, yet increased Silybum $(0.08 \mathrm{~g})$. P. stratiotes decreased shoot weight in all test species. At lower concentration E. crassipes enhanced root weight in wild oat and Silybum $(7.7,5.7 \mathrm{~g}$ ), while $P$. stratiotes reduced $(0.01 \mathrm{~g}$ each), yet enhanced it at higher concentration $(7.7 \mathrm{~g}$ each). The extracts negatively affected all test species, but the weeds performed well at lower concentration. These aquatic weeds can be used as mulch for weed management in wheat due to their allelopathy potential towards noxious weeds of wheat.
\end{abstract}

Keywords: weed management, allelopathy, aquatic weeds, weeds utilization

\section{Introduction}

Allelopathy is an old concept but has recently received greater attention from researchers and farmers globally (De Albuquerque et al., 2010). The word allelopathy was first coined by Molisch (1937) to point at both the harmful and useful biochemical interactions among plants and even on microbes (Fareed et al., 2008; Bobbarala et al., 2009). The allelochemicals produced escape into the environment is part of the plant defense mechanism, which might be harmful or beneficial nearby plants (Rice, 1984). The detrimental effect of weeds and crops is a complicated phenomenon and one cannot be $100 \%$ accurate to separate physical competition than allelopathy (Batish et al., 2007). However, in allelopathy allelochemicals are released to the plant environment which obstruct or favour the growth of associated plant while in competition substances are taken out of the plant environment (May and Ash, 1990). Most weeds have allelochemicals that adversely affect seed germination and seedlings growth of crop as well as other weeds (Mulatu et al., 2009; Shibu and Andrew, 1998; Rice, 1984; Delabays et al., 2004). So, knowledge about the nature of weeds is necessary in order to reduce their effects on crops. Usually, these allelochemicals are secondary metabolites released into the environment through leaching, root exudation, volatilization and decomposition of plant residues. These chemicals with allelopathic potential are present 
in almost all plants in many tissues and are released in broad quantities that affect the neighbouring or successional plant under specific conditions (Putnam, 1988).

In weed management, allelopathy is being utilized in different ways like stubble mulches, allelopathic crops in rotation and intercropping systems (Cheema et al., 1988; Narwal, 2000). As wheat is the staple food of the majority of the population in many regions of the world, grown on large land area than any other crop and is the most important food source for human beings. New approaches and sustainable production technologies are required for wheat to cope with the food scarcity and population pressure. Yield losses due to weeds must be minimized through sustainable and environmentally safe strategies. The plant with strong allelopathic potential might be used as a bioherbicide for weed control in order to decrease dependence on synthetic herbicides (Sodaeizadehet et al., 2009).

Wild oat (Avena fatua) is among the worst grassy weeds of wheat in many countries including Pakistan, reducing crop yield by about 30\% (Hobbs et al., 1998). According to Martin and Field (1988) wild oat is more competitive than wheat when sown simultaneously. While among the broad leaf weeds of wheat, milk thistle (Silybum marianum) is the most competitive, noxious and troublesome due to rapid growth, chocking rosette formation and thorny nature; hindering physical control, so milk thistle infested fields are left unharvested often. Both are winter annual with luxurious rapid growth (Young et al., 1978; Austin et al., 1988; Groves and Kaye, 1989). Being a major weed in wheat it causes considerable yield reduction (Omtvedt, 1984; Khan and Marwat, 2006; Shimi et al., 2006). Although its management through herbicides is easier than grassy weeds but species shift as well as herbicide-resistance may be created (Bhowmik and Inderjit, 2003). Therefore cultural and ecological approaches are getting popularity and the global market of chemical free produce is increasing (Roseboro, 2006). In the quest for new ecological and natural approaches for weeds management the use of allelopathic plants offers a promising option. Thousands of alien species like water hyacinth introduced intentionally or un-intentionally had become a threat as biological pollution to the natural environment and diversity of native species (Qureshi et al., 2014).

Water hyacinth (E. crassipes) is an aquatic weed (Lalitha et al., 2012) and contains many phytochemicals (Nyananyo et al., 2007; Ndubuisi et al., 2007; Lata and Dubey, 2010; Jayanthi and Lalitha, 2011; Greca et al., 2009). The novel 8-phenylphenalenone type compounds were isolated from its roots and leaves (Hölscher and Schneider, 2005). It is reported to have wound healing effect (Ali et al., 2010) as well as anticancer activity (Ali et al., 2009). The antioxidative property of E. crassipes makes this plant as an alternative and convenient antioxidizing agent (Bodo et al., 2004; Jayanthi and Lalitha, 2012) besides being the world worst weed. For the first time it was biocontrolled through Eichhornia weevil (Adams et al., 2002). It has a potential to successfully control of the filarial vector Culex quinquefasciatus (Jayanthi et al., 2012). The plant also exhibited the antimicrobial and antialgal activities (Shanab et al., 2010). However, it is an efficient plant in taking up the toxic metals from water (Dandelot et al., 2008). Yet the infested water becomes more eutrophic due to water hyacinth biomass (Gao and $\mathrm{Li}, 2004$ ). The increased water loss due to water hyacinth evapotranspiration, flow retardation, health hazards and the altered chemistry of the hydrosoil has created several key problems (Awad, 2008). It can strongly inhibit the biomass of weeds if applied to paddy rice at 1-2 tonne ha ${ }^{-1}$ of plant material to the field (Xuan et al., 2005). 
Similarly water lettuce ( $P$. stratiotes $\mathrm{L})$ is another noxious free floating perennial fast growing weed (Sculthorpe, 1967; Holm et al., 1977) producing 60-110 tons ha ${ }^{-1}$ year $^{-1}$ (Gumbricht, 1993) due to its tremendous ability to extract nutrients from the waste or eutrophic water (Fonkou et al., 2002). Like water hyacinth it decreased the growth of some algae (Alliotta et al., 1991; Greca et al., 1992) as its extract contains many cytotoxic steroids (Ayyad, 2002). In our country it was first reported from South Waziristan in 1972, but now it is found everywhere in the whole country. Like duckweed it can be used for the purification of municipality water (Kesaano, 2011). The utilization of this plant for weed management due to its allelopathy on terrestrial weeds would prove a useful source for weed management (Khan, et al., 2014). The water extracts of allelopathic plants can be used at a minimum concentration like of $10 \mathrm{~g} \mathrm{~L}^{-1}$ for the management of the weeds (El-Gawad, 2014). That is why the current experiment is designed to evaluate the allelopathic effect of $E$. crassipes and $P$. stratiotes on germination and growth of wheat and its associated troublesome weeds and to utilize the enormous biomass of aquatic weeds for the eco-friendly, organic and economical weed control in wheat.

\section{Materials and methods}

\section{Collection of plant material}

The aquatic plants $E$. crassipes L. and P. stratiotes L. were collected from the local stream of Maini District Swabi. Both the plants were washed off mud, dried, ground to powder for extract preparation. Wheat, wild oat and milk thistle seeds were obtained from Malakandair farm, The University of Agriculture Peshawar and tested for seed germination prior to the conduction of experiment. Only healthy seeds were chosen.

\section{Extract preparation}

100 grams of powder was taken from the dried mass of E. crassipes L. and $P$. stratiotes L each and were dissolved in one Liter of tap water, to get $10 \%$ solution of both the plant extracts. The extracts were diluted to $5 \%$ by mixing the extract with an equal amount of tap water for both the species. The mixtures were kept in the laboratory at room temperature. After $24 \mathrm{hrs}$ the extract was filtered through Muslin cloth and transferred into a flask and tied with cork and labeled the flask with plant name and extract concentration. The extracts were prepared in hygienic environment and cleanliness was also kept in mind in order to avoid every kind of contamination. The petri dishes were sterilized in the autoclave so that it becomes free of germs and other pathogens. The filter paper (whatman filter paper) was put into them in order to keep the seeds moist during germination process and protect the seeds from drying. The diameter of the petri dishes was $9 \mathrm{~cm}$ in size.

\section{Seed soaking}

10 seeds of each wheat, wild oat and Silybum were put and soaked in the $10 \%$ concentration solution of E. crassipes L. and P. stratiotes L., respectively. Similarly 10 seeds from each of species were also soaked in 5\% concentration solutions of both the plants. For the purpose of comparison a 10 seeds from wheat, wild oat and Silybum 
were soaked in tap water. After the completion of this process all the Petri dishes with soaked seeds were kept at room temperature.

\section{Arrangement of experiment}

This experiment was conducted in the Lab at the Department of Weed Sciences, The University of Agriculture Peshawar Pakistan during May 2014, for the evaluation of the effect of $E$. crassipes and P. stratiotes on the growth and germination of wheat and its associated weeds. This experiment was designed in a Completely Randomized Design (CRD) with 15 treatments replicated three times.

Test species (the species with allelopathic potential)

- Eichhornia crassipes

- Pistia stratiotes

Target species (the species to be tested against allelopathy)

- Wheat (Triticum aestivum)

- Wild oat (Avena fatua)

- Milk thistle (Silybum marianum)

\section{Arrangement of treatments}

Ten seeds from each target species (wheat, oat and Silybum) were put in first petri dish. The seeds were soaked in the respective petri dish with $10 \%$ and 5\% concentrations of each test species extracts (E. crassipes and P. stratiotes), respectively according to the mentioned plan of work. A control treatment where seeds were soaked in tap water was included for comparison.

\section{The data was recorded after 20 days on the following parameters:}

1. Germination (\%): By counting the number of germinated seeds in each treatment and divided the number by the total seeds in each treatment, percent germination was recorded.

2. Fresh root weight plant $^{-1}(\mathrm{~g})$ : With the help of electronic balance fresh root weight was measured of five representative plants in grams and converted it to average fresh root weight.

3. Shoot length plant ${ }^{-1}(\mathrm{~cm})$ : Through the measuring tape, shoot lengths of test species were measured and average lengths were determined in $\mathrm{cm}$.

4. Fresh shoot weight/plant $(g)$ : With the help of electronic balance fresh shoot weight was measured of five representative plants in grams and converted it to average fresh shoot weight.

\section{Results and discussion}

\section{Germination (\%)}

Statistical analysis of the data showed that both the allelopathic plants' (water hyacinth and water lettuce) aqueous extracts have affected the germination of the test 
species (wheat, wild oat, \& milk thistle) as shown in Table 1. Wild oat has been greatly affected than milk thistle while their effect on wheat has been very little. However by increasing the concentration of water hyacinth from zero to 5 and $10 \%$ wheat germination was decreased from $43.33 \%$ to $26.70 \%$ and $20.00 \%$, respectively. Yet, the wheat still germinated while the germination of other species was almost completely inhibited as shown in the Figure $1 b$. The same trend is found for the increase in concentration of water lettuce for the germination of wheat (Table 1). At $5 \%$ concentration the germination was $36.70 \%$, while at $10 \%$ the germination was decreased up to $26.70 \%$. But in case of wild oat, the highest concentration $(10 \%)$ of water hyacinth decreased the germination of wild oat to zero $(0.00 \%)$ i.e. there was no germination at all (Fig. 1a), while at $5 \%$ its germination was very nominal i.e. only $3.33 \%$. Similarly, high concentration of water lettuce $(10 \%)$ also decreased wild oat germination up to $6.7 \%$ as compared to $5 \%(13.33 \%)$ and control $(10.00 \%)$. In case of milk thistle at $5 \%$ concentration of water hyacinth the germination $20 \%$, while increasing the extract concentration to $10 \%$ the germination decreased to $10 \%$ as compared to control where the germination is $50 \%$. In contrast, the milk thistle seed germination was $10 \%$ at $5 \%$ aqueous extract of water lettuce and the germination increased to $20 \%$ when the concentration increased to $10 \%$ (Fig. 1c), whereas the germination of milk thistle was $50 \%$ in the control treatment (Table 1). These findings are in line with the work of Chai et al. (2013) who also reported that water hyacinth extract reduced the total percentage and speed of germination, yet the mode of action of the extracts is still unknown.

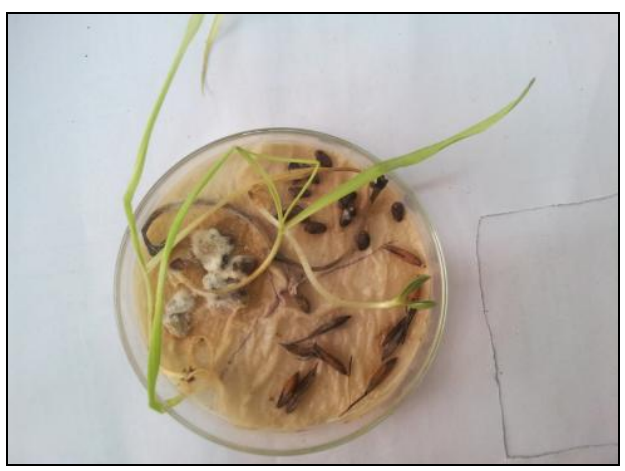

a)

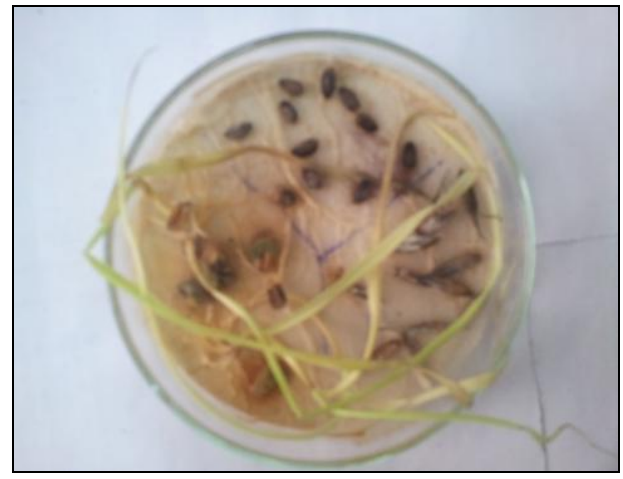

b) 


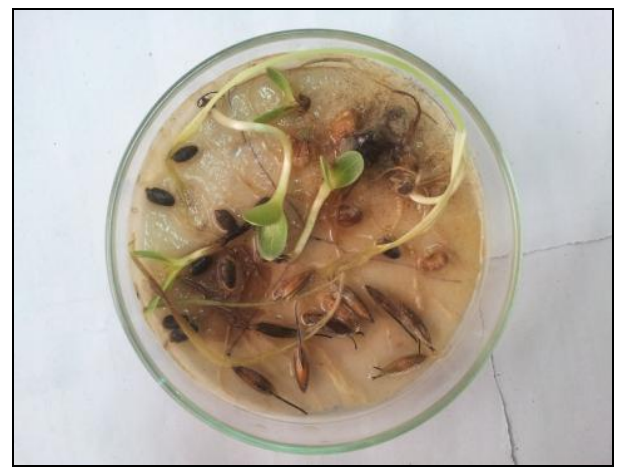

c)

Figure 1. Show the significant allopathic effect of various concentrations of the aqueous extracts of water hyacinth and water lettuce on the test species i.e. a. wild oat \& milk thistle, $b$. wheat \& milk thistle and c. wild oat and wheat.

Table 1. Germination (\%) of wheat, wild oat and milk thistle as affected by various concentration of the aqueous extracts of water hyacinth and water lettuce

\begin{tabular}{|c|c|c|c|c|c|c|}
\hline \multirow{3}{*}{ Target plant species } & \multicolumn{5}{|c|}{ Allelopathic plants used (water extracts) } & \multirow{3}{*}{$\begin{array}{c}\text { Species } \\
\text { means }\end{array}$} \\
\hline & \multicolumn{2}{|c|}{$\begin{array}{l}\text { Water hyacinth } \\
\text { (E. crassipes } \text { L.) }\end{array}$} & \multicolumn{2}{|c|}{$\begin{array}{l}\text { Water lettuce } \\
(P \text {. stratiotes } \text { L. })\end{array}$} & \multirow{2}{*}{$\begin{array}{c}\text { Control } \\
\text { treatment } \\
0 \% \text { conc. }\end{array}$} & \\
\hline & $\begin{array}{l}10 \% \\
\text { conc. }\end{array}$ & $\begin{array}{l}5 \% \\
\text { conc. }\end{array}$ & $\begin{array}{l}10 \% \\
\text { conc. }\end{array}$ & $\begin{array}{c}5 \% \\
\text { conc. }\end{array}$ & & \\
\hline $\begin{array}{c}\text { Wheat (Triticum } \\
\text { aestivum } \mathbf{L} .)\end{array}$ & 20.00 cde & $26.70 \mathrm{bcd}$ & $26.70 \mathrm{bcd}$ & $36.70 \mathrm{abc}$ & $43.33 \mathrm{ab}$ & $30.68 \mathrm{a}$ \\
\hline $\begin{array}{l}\text { Wild oat (Avena } \\
\text { fatua } \mathrm{L} .)\end{array}$ & $0.00 \mathrm{e}$ & $3.33 \mathrm{e}$ & $6.7 \mathrm{de}$ & $13.33 \mathrm{de}$ & $10.00 \mathrm{de}$ & $6.67 \mathrm{~b}$ \\
\hline $\begin{array}{c}\text { Milk thistle (Silybum } \\
\text { marianum } \text { L.) }\end{array}$ & $10.00 \mathrm{de}$ & 20.00 cde & 20.00 cde & $10.00 \mathrm{de}$ & $50.00 \mathrm{a}$ & $22.00 \mathrm{ab}$ \\
\hline $\begin{array}{c}\text { Concentration } \\
\text { means } \\
\end{array}$ & $10.00 \mathrm{~b}$ & $16.70 \mathrm{ab}$ & $17.80 \mathrm{ab}$ & $20.01 \mathrm{ab}$ & $34.44 \mathrm{a}$ & \\
\hline
\end{tabular}

LSD value: 21.670

\section{Root weight (g)}

Statistical analysis of the data showed that aqueous extracts from both the allelopathic plants (water hyacinth and water lettuce) have affected the test species i.e. wheat, wild oat, and the milk thistle significantly (Table 2). Both the extracts greatly affected wheat than milk thistle while wild oat has been less affected. On the basis of the statistical analysis it was shown that by using increased concentration of $E$. crassipes the root weight of wheat decreases. At zero concentration the root weight of wheat was $0.10 \%$ while at $5 \%$ concentration the root weight of wheat was up to $0.08 \%$, while at $10 \%$ concentration root weight was decreased to $0.07 \%$. The same trend is found for the increase in concentration of $P$. stratiotes for the root weight of wheat (Table 2). Of water lettuce was taken up to $10 \%$ the root weight of wheat has decreased up to $0.04 \%$. The concentration being up to $5 \%$, so the root weight of wheat increased up to $0.07 \%$. But in case of control, the highest increase in root weight was recorded for wheat at $0 \%$ concentration up to $0.10 \%$. Increased concentration of E. crassipes up to $10 \%$ decreased the root weight of wild oat up to $0.00 \%$. Also, by using the 
concentration of this plant up to $5 \%$ increased the root weight of wild oat up to $7.7 \%$. Likewise, increased concentration of $P$. stratiotes up to $10 \%$ increased root weight up to $7.7 \%$, while at $5 \%$ concentration the root weight of wild oat decreased up to $0.01 \%$. Also, in process of control the root weight of wild oat up to $0.01 \%$. Similarly, the $E$. crassipes produced the result up to $0.01 \%$ at $10 \%$ concentration in case of milk thistle. But at $5 \%$ concentration the root weight increased up to $5.7 \%$. Likewise, by using $10 \%$ concentration of $P$. stratiotes, the root weight of milk thistle increases surprisingly up to $7.7 \%$. But at $5 \%$ concentration the unexpected result was shown by water lettuce on milk thistle on $5 \%$ concentration produced $0.01 \%$ decrease in root weight. The effect on control was $0.05 \%$ on milk thistle. These results are in conformity with the work of Chai et al., (2013), who reported that water hyacinth extract reduced the plant germination and fresh weight and induced similar biochemical responses in the root tissues of seedlings of both test species.

Table 2. Root weight ( $g$ ) of wheat, wild oat and milk thistle as affected by various concentration of the aqueous extracts of water hyacinth and water lettuce

\begin{tabular}{|c|c|c|c|c|c|c|}
\hline \multirow{3}{*}{$\begin{array}{c}\text { Target plant } \\
\text { species }\end{array}$} & \multicolumn{5}{|c|}{ Allelopathic plants used (water extracts) } & \multirow{3}{*}{$\begin{array}{c}\text { Species } \\
\text { means }\end{array}$} \\
\hline & \multicolumn{2}{|c|}{$\begin{array}{l}\text { Water hyacinth } \\
\text { (E. crassipes L.) }\end{array}$} & \multicolumn{2}{|c|}{$\begin{array}{l}\text { Water lettuce } \\
(P \text {. stratiotes } \mathrm{L} .)\end{array}$} & \multirow{2}{*}{$\begin{array}{c}\text { Control } \\
\text { treatment } \\
0 \% \text { conc. }\end{array}$} & \\
\hline & $\begin{array}{l}10 \% \\
\text { conc. }\end{array}$ & $\begin{array}{l}5 \% \\
\text { conc. }\end{array}$ & $\begin{array}{l}10 \% \\
\text { conc. }\end{array}$ & $\begin{array}{c}5 \% \\
\text { conc. }\end{array}$ & & \\
\hline $\begin{array}{c}\text { Wheat (Triticum } \\
\text { aestivum } \text { L.) }\end{array}$ & $0.07 \mathrm{abc}$ & $0.08 \mathrm{ab}$ & 0.04 cde & $0.07 \mathrm{abc}$ & $0.10 \mathrm{a}$ & $0.07 \mathrm{c}$ \\
\hline $\begin{array}{l}\text { Wild oat (Avena } \\
\text { fatua L.) }\end{array}$ & $0.00 \mathrm{f}$ & $\begin{array}{c}7.7 * 10^{-3} \mathrm{f} \\
\text { means } 0.007\end{array}$ & $7.7 * 10^{-3} \mathrm{f}$ & $0.01 \mathrm{def}$ & $0.01 \mathrm{ef}$ & $3.08 \mathrm{a}$ \\
\hline $\begin{array}{l}\text { Milk thistle } \\
\text { (Silybum } \\
\text { marianum L.) }\end{array}$ & 0.01 ef & $5.7 * 10^{-3} \mathrm{f}$ & $7.7 * 10^{-3} \mathrm{f}$ & 0.01def & $0.05 \mathrm{bc}$ & $2.69 b$ \\
\hline $\begin{array}{c}\text { Concentration } \\
\text { means }\end{array}$ & $0.02 \mathrm{c}$ & $4.49 \mathrm{~b}$ & $5.14 \mathrm{a}$ & $0.03 \mathrm{c}$ & $0.05 \mathrm{c}$ & \\
\hline
\end{tabular}

LSD value: 0.0381

\section{Shoot length (cm)}

The peer review of the data revealed that shoot length of all the tested species (wheat, oat and milk thistle) were significantly affected by the extracts of E. crassipes, $P$. stratiotes and their corresponding concentrations (Table 3). The statistical analysis of the data shows, that shoot length of all the verified species inversely proportional to the different extracts concentration. Wild oat has been more effected than rest of wheat and Silybum, while milk thistle less effected than oat and more than wheat.

By using $10 \%$ extract concentration of E. crassipes tremendously increased the shoot length of wheat up to $8.44 \%$, while at $5 \%$ concentration slightly decreasing was recorded up to $8.33 \%$. By applying $10 \%$ and 5\% extracts concentration of $P$. stratiotes on wheat, same results were recorded $7.88 \%$. Data regarding to shoot length of wheat, significantly increased was found at the rate up to $12.88 \%$ in case of control by using distilled water. Using $10 \%$ extract of E. crassipes, the shoot length of wild oat decreased to $0.00 \%$, and magnificently increased up to $0.88 \%$ by applying $5 \%$ extract concentration. Similarly, increasing the concentration of Pistia up to $10 \%$, decreased the shoot length of wild oat up to $2.77 \%$, while the shoot length marvelously increased up 
to $5.55 \%$ by applying $5 \%$ concentration. Also, in case of control the shoot length of wild oat increased up to $3.65 \%$, by utilizing $10 \%$ aqueous extract of E. crassipes showed surprising increase in shoot length of milk thistle at rate of $4.33 \%$, while at $5 \%$ concentration revealed the impressive decrease up to $1.11 \%$. By the same way, increasing the concentration of E. crassipes up to $10 \%$ enormously increased the shoot length of milk thistle up to $17.77 \%$, while at $5 \%$ concentration the shoot length rate wonderfully decreased up to $1.77 \%$. Furthermore, in case of control by using distilled water, data concerning to shoot length of milk thistle increased up to 5.33\% (Table 3). Similar results have been reported by Chai et al., (2013) who stated that water hyacinth water extracts reduced root length and fresh weight of germinating seeds which might be due to the $\mathrm{H}_{2} \mathrm{O}_{2}$ increase production and peroxidase activity in the root tissues. So, the shoot might have been affected by the same process.

Table 3. Shoot length (cm) of wheat, wild oat and milk thistle as affected by various concentration of the aquas extracts of water hyacinth and water lettuce

\begin{tabular}{|c|c|c|c|c|c|c|}
\hline \multirow{3}{*}{$\begin{array}{l}\text { Target plant } \\
\text { species }\end{array}$} & \multicolumn{5}{|c|}{ Allelopathic plants used (water extracts) } & \multirow{3}{*}{$\begin{array}{c}\text { Species } \\
\text { means }\end{array}$} \\
\hline & \multicolumn{2}{|c|}{$\begin{array}{l}\text { Water hyacinth } \\
\text { (E. crassipes } \text { L. })\end{array}$} & \multicolumn{2}{|c|}{$\begin{array}{l}\text { Water lettuce } \\
\text { (P. stratiotes } \text { L.) }\end{array}$} & \multirow{2}{*}{$\begin{array}{c}\text { Control } \\
\text { treatment } \\
0 \% \text { conc. }\end{array}$} & \\
\hline & $\begin{array}{l}10 \% \\
\text { conc. }\end{array}$ & $\begin{array}{c}5 \% \\
\text { conc. }\end{array}$ & $\begin{array}{l}10 \% \\
\text { conc. }\end{array}$ & $\begin{array}{c}5 \% \\
\text { conc. }\end{array}$ & & \\
\hline $\begin{array}{c}\text { Wheat (Triticum } \\
\text { aestivum } \mathbf{L} .)\end{array}$ & $8.44 \mathrm{bc}$ & $8.33 \mathrm{bc}$ & $7.88 \mathrm{bc}$ & $7.88 \mathrm{bc}$ & $12.88 \mathrm{ab}$ & 9.08 \\
\hline $\begin{array}{l}\text { Wild oat (Avena } \\
\text { fatua } \mathrm{L} .)\end{array}$ & $0.00 \mathrm{c}$ & $0.88 \mathrm{c}$ & $2.77 \mathrm{c}$ & $5.55 \mathrm{bc}$ & $3.65 \mathrm{c}$ & 2.57 \\
\hline $\begin{array}{l}\text { Milk thistle } \\
\text { (Silybum } \\
\text { marianum L.) }\end{array}$ & $4.33 \mathrm{c}$ & $1.11 \mathrm{c}$ & $17.77 \mathrm{a}$ & $1.77 \mathrm{c}$ & $5.33 \mathrm{bc}$ & 6.06 \\
\hline $\begin{array}{c}\text { Concentration } \\
\text { Means }\end{array}$ & 4.25 & 3.44 & 9.47 & 5.06 & 7.28 & \\
\hline
\end{tabular}

\section{Shoot weight (g)}

The statistical analysis of the data showed that both the allelopathic plants (water hyacinth and water lettuce) water extracts have affected the test species I. e wheat, wild oat, and the milk thistle (Table 4). wheat and milk thistle has been greatly affected while wild oat has been less affected by the both allelopathic plants comparatively. On the basis of the statistical analysis it was shown that the increase in the concentration of $E$. crassipes decreased the shoot weight of wheat. At zero concentration the shoot weight of wheat was $0.11 \%$ while at $5 \%$ concentration the shoot length of wheat has increased up to $0.09 \%$ while at $10 \%$ concentration shoot length has slightly decreased up to $0.06 \%$. The same trend is found for the increase in concentration of water lettuce for the shoot weight of wheat (Table 4). Of P. stratiotes was taken up to $10 \%$ the shoot weight of wheat has decreased up to $0.05 \%$. But if the concentration being up to $5 \%$ so the shoot weight of wheat increases up to $0.076 \%$. But in case of control, the shoot weight was recorded for wheat at $0 \%$ concentration up to $0.11 \%$. Increased concentration of $E$. crassipes up to $10 \%$ decreased the shoot weight of wild oat up to $0.00 \%$. Also, by using the concentration of this plant up to $5 \%$ slightly increased the shoot weight of wild oat up to $0.01 \%$. Likewise, by increasing concentration of $P$. stratiotes up to $10 \%$, 
decreased shoot weight up to $0.01 \%$, while at $5 \%$ concentration the shoot weight of wild oat increase up to $0.02 \%$. Also, in process of control the height increase was recorded for shoot weight of wild oat up to $5.33 \%$. Similarly, the $E$. crassipes produced the result up to $0.08 \%$ on $10 \%$ concentration in case of milk thistle. But at $5 \%$ concentration the shoot weight decreases up to $0.05 \%$. Likewise, by using $10 \%$ concentration of $P$. stratiotes, the shoot weight of milk thistle decreases up to $0.05 \%$. But at $5 \%$ concentration the result was shown by $P$. stratiotes on milk thistle on $5 \%$ concentration produced $0.07 \%$ increase in shoot weight. The effect on control was $0.19 \%$ on milk thistle. As the water extracts affected the root weight so, it can be expected to have a negative impact on the shoot weight also (Chai et al., 2013).

Table 4. Shoot weight ( $g$ ) of wheat, wild oat and milk thistle as affected by various concentration of the aqueous extracts of water hyacinth and water lettuce

\begin{tabular}{|c|c|c|c|c|c|c|}
\hline \multirow{3}{*}{$\begin{array}{l}\text { Target plant } \\
\text { species }\end{array}$} & \multicolumn{5}{|c|}{ Allelopathic plants used (water extracts) } & \multirow{3}{*}{$\begin{array}{l}\text { Species } \\
\text { means }\end{array}$} \\
\hline & \multicolumn{2}{|c|}{$\begin{array}{l}\text { Water hyacinth } \\
\text { (E. crassipes L.) }\end{array}$} & \multicolumn{2}{|c|}{$\begin{array}{l}\text { Water lettuce } \\
\text { (P. stratiotes L.) }\end{array}$} & \multirow{2}{*}{$\begin{array}{c}\text { Control } \\
\text { treatment } \\
0 \% \text { conc. }\end{array}$} & \\
\hline & $\begin{array}{l}10 \% \\
\text { conc. }\end{array}$ & $\begin{array}{c}5 \% \\
\text { conc. }\end{array}$ & $\begin{array}{l}10 \% \\
\text { conc. }\end{array}$ & $\begin{array}{c}5 \% \\
\text { conc. }\end{array}$ & & \\
\hline $\begin{array}{c}\text { Wheat (Triticum } \\
\text { aestivum } \mathbf{L} .)\end{array}$ & 0.06 bcde & $0.09 \mathrm{~b}$ & $\begin{array}{l}0.05 \\
\text { bcdef }\end{array}$ & $0.076 \mathrm{bcd}$ & $0.11 \mathrm{~b}$ & $0.07 \mathrm{~b}$ \\
\hline $\begin{array}{c}\text { Wild oat (Avena } \\
\text { fatua } \mathrm{L} \text {.) }\end{array}$ & $0.00 \mathrm{f}$ & $0.01 \mathrm{def}$ & $0.01 \mathrm{def}$ & 0.02 cdef & 5.33 ef & $1.07 \mathrm{a}$ \\
\hline $\begin{array}{l}\text { Milk thistle } \\
\text { (Silybum } \\
\text { marianum L.) }\end{array}$ & $0.08 \mathrm{bc}$ & 0.05 bcdef & $\begin{array}{c}0.05 \\
\text { bcdef }\end{array}$ & $0.07 \mathrm{bcd}$ & $0.19 \mathrm{a}$ & $0.08 \mathrm{~b}$ \\
\hline $\begin{array}{c}\text { Concentration } \\
\text { means }\end{array}$ & $0.04 \mathrm{~b}$ & $0.05 \mathrm{~b}$ & $0.03 \mathrm{~b}$ & $0.05 \mathrm{~b}$ & $1.87 \mathrm{a}$ & \\
\hline
\end{tabular}

LSD value: 0.0671

\section{REFERENCES}

[1] Austin, M. P., Fresco, L. F. M., Nicholls, A. O., Groves, R. H., Kaye, P. E. (1988): Competition, relative yield estimation \& interpretation at different densities under various nutrient concentrations using Silybum marianum \& Cirsium vulgare. - Journal of Ecology 76(1):157-171.

[2] Ali, H., Lata, N., Ahi., J., Ganesh, N. (2010): Evaluation of wound-healing activity of Eichhornia crassipes: A novel approach. - Drug Invention Today 2(3): 212-214.

[3] Ali, H, Patel, M., Ganesh, N., Ahi, J. (2009): The world's worst aquatic plant as a safe cancer medicine - Antitumor activity on melanoma induced mouse by Eichhornia crassipes: in vivo studies. - Journal of Pharmacy Research 2(8): 1365-1366.

[4] Adams, C. S., Boar, R. R., Hubble, S. D., Gikungu, M., Harper, M. D., Hickley, P., Tarras-Wahlberg, N. (2002): The dynamics and ecology of exotic tropical plants in floating plant mats: Lake Naivasha, Kenya. - Hydrobiologia 488(1): 115-122.

[5] Awad, H. E. A. (2008): Ecology and Adaptation of water hyacinth in the Nile Delta Ecosystem. - Master of Science Thesis, Department of Botany, Faculty of Sciences, Cairo University.

[6] Alliotta, G., Monaco, P., Pinto, G., Pollio, A., Previtera, L. (1991): Potential allelochemicals from Pistia stratiotes L. - Journal of Chemical Ecology 17(11): 22232234. 
[7] Ayyad, S N. (2002): A new cytotoxic stigmastane steroid from Pistia stratiotes. Pharmazie 57(3): 212-214.

[8] Batish, D. R., Singh, H. P., Kohli, R. K., Kaur, S., Saxena, D. B., Yadav, S. (2007): Assessment of parthenin against some weeds. - Zeitschrift für Naturforschung 62c:367372.

[9] Bhowmik, P. C., Inderjit. (2003): Challenges and opportunities in implementing allelopathy for natural weed management. - Crop Protection 22(4): 661-671.

[10] Bobbarala, V., Katikala, P. K., Naidu, K. C., Penumajji, S. (2009): Antifungal activity of selected plant extracts against phytopathogenic fungi Aspergillus niger F2723. - Indian Journal of Science and Technology 2(4): 87-90.

[11] Bodo, R., Azzouz, A., Hausler, R. (2004): Antioxidative activity of water hyacinth components. - Plant Science 166(4): 893-899.

[12] Chai, T. T., Ngoi, J. C., Wong, F. C. (2013): Herbicidal potential of Eichhornia crassipes leaf extract against Mimosa pigra and Vigna radiata. - International Journal of Agricultural and Biological Engineering 15(5): 835-842.

[13] Cheema, Z. A., Ahmad, S., Majeed, S., Ahmad, N. (1988): Allelopathic effects of wheat (Triticum aestivum L.) straw on germination and seedling growth of two weed species and cotton. - Pakistan Journal of Weed Sciences Research 1(2): 118-122.

[14] Delabays, M. N. G., de Jofferey, J. P., Bohre, C. (2004): Demonstration in a cultivated fields, of the relealty of the phenomenon of allelopathy. - 12th International Conference of Weed Biology, pp. 97-104.

[15] De Albuquerque, M. B., dos Santo, R. C., Lima, L. M., Melo, F. P. A., Nogueria, R. J. M. C., Camara, C. A. G., Romos., A. R. (2010): Allelopathy, an alternative tool to improve cropping systems. A review. - Agronomy for Sustainable Development 31(2): 379-395.

[16] Dandelot, S., Robles, C., Pech, N., Cazaubon, A., Verlaque, R. (2008): Allelopathic potential of two invasive alien Ludwigia spp. - Aquatic Botany 88(4): 311-316.

[17] El-gawad, A. M. A. (2014): Ecology and allelopathic control of Brassica tournefortii in reclaimed areas of the Nile Delta, Egypt. - Turkish Journal of Botany 38(2): 347-357.

[18] Fareed, M. F., Haroon, A. M., Rabeh, S. A. (2008): Antimicrobial activity of some macrophtyes from Lake Manzalah (Egypt). - Pakistan Journal of Biological Sciences 11(21): 2454-2463.

[19] Fonkou, T., Agendia, P., Kengne, I., Akoa, A., Nya, J. (2002): Potentials of water lettuce (Pistia stratiotes) in domestic sewage treatment with macrophytic lagoon system in Cameroon. - Proceedings of International Symposium on Environmental Pollution Control and Waste Management 7-10 January, Tunis, p.709-714.

[20] Groves, R. H. Kaye, P. E. (1989): Germination and phenology of seven introduced thistle species in Southern Australia. - Australian Journal of Botany 37(4): 351-359.

[21] Greca, M. D., Molinaro, A., Monaco, P., Previtera, L. (1992): Dimeric phenalene metabolites from Eichhornia crassipes. - Tetrahedron 48(19): 3971-3976.

[22] Greca, M. D., Previtera, L., Zarrelli, A. (2009): Structures of new phenylphenalenerelated compounds from Eichhornia crassipes (water hyacinth). - Tetrahedron 65(39): 8206-8208.

[23] Gao, L., Li, B. (2004): The study of a specious invasive plant, water hyacinth (Eichhornia crassipes): Achievements and challenges. - Acta Phytoecological Sinica 28(6): 735-752.

[24] Gumbricht, T. (1993): Nutrients removal processes in freshwater submersed macrophyte system. - Ecological Engineering 2(1): 1-30.

[25] Hobbs, P. R., Sayre, K. D., Monasterio, J. I. O. (1998): Increasing wheat yields sustainably through agronomic means. - NRG Paper 98-01. Mexico, D.F.: Mexico.

[26] Hölscher, D., Schneider, B. (2005): The biosynthesis of 8-phenylphenalenones from Eichhornia crassipes involves a putative aryl migration step. - Phytochemistry 66(1): 5954.

[27] Holm, L. G., Plucknett, D. L., Pancho, J. V., Herberger, J. P., (1977): The world's worst weeds. - The University Press of Hawaii, Honolulu. 
[28] Inam, B., Hussain, F. (1988): Allelopathic effects of Silybum marianum Gaertn. - Sarhad Journal of Agriculture 4(4): 481-494.

[29] Jayanthi, P, Lalitha, P. (2011): Reducing power of the solvent extracts of Eichhornia crassipes (Mart.) Solms. - International Journal of Pharmacy \& Pharmaceutical Sciences 3(3): 126-128.

[30] Jayanthi, P., Lalitha, P. (2012): DPPH scavenging assay of the solvent extracts and fractionates of Eichhornia crassipes (Mart.) Solms. - Journal of Pharmacy Research 5(2): 946-948.

[31] Jayanthi, P., Laitha, P., Arthi, N. (2012): Larvicidal and pupicidal activity of extracts and fractionates of Eichhornia crassipes (Mart.) Solms against the filarial vector Culex quinquefasciatus Say. - Parasitology Research 111(5): 2129-2135.

[32] Khan, M. A., Marwat, K. B. (2006): Impact of crop and weed densities on competition between wheat and Silybum marianum Gaertn. - Pakistan Journal of Botany 38(4): 12051215.

[33] Khan, M. A., Marwat, K. B., Gul, B., Wahid, F., Khan, H., Hashim, S. (2014): Pistia stratiotes L. (Araceae): Phytochemistry, use in medicines, phytoremediation, biogas and management options. - Pakistan Journal of Botany 46(3): 851-860.

[34] Kesaano, M. (2011): Sustainable management of duck weed biomass grown for nutrient control in municipal wastewaters. - Dissertations. Utah State Univiversity Logan, Utah, p.879.

[35] Lalitha, P., Sripathi, K. S., Jayanthi, P. (2012): Secondary metabolites of Eichhornia crassipes (Water hyacinth): A Review (1949 to 2011). - Natural Product Communications 7(9): 1249- 1256.

[36] Lata, N., Dubey, V. (2010): Preliminary phytochemical screening of Eichhornia crassipes: the world's worst aquatic weed. - Journal of Pharmacy Research 3(6): 12401242.

[37] Molisch, H. (1937): Der Einfluss einer Pflanze auf die andere. - Allelopathic Fischer, Jena.

[38] May, F. E., Ash, J. E. (1990): An assessment of the allelopatic potential of Ecualyptus. Australian Journal of Botany 38(3): 245-254.

[39] Mulatu, W., Gezahegn, B., Solomon, T. (2009): Allelopathic effects of an invasive alien weed Parthenium hysterophorus L. compost on lettuce germination and growth. African Journal of Agricultural Research 4(11):1325-1330.

[40] Martin, M. P. L. .D., Field, R. J. (1988): Influence of time of emergence of wild oat on competition with wheat. - Weed Research 28(2): 111-116.

[41] Narwal, S. S. (2000): Weed management in rice: wheat rotation by allelopathy. Critical reviews in plant sciences 19(3): 249-266.

[42] Nyananyo, B. L., Gijo, A. H., Ogamba, E. N. (2007): The physico-chemistry and distribution of water hyacinth (Eichhornia crassipes) on the river Nun in the Niger Delta. - Journal of Applied Science \& Environmental Management 11(3): 133-137.

[43] Ndubuisi, J. A., Emeka, E. O., Ukiwe, L. N. (2007): Physicochemical properties of chloroform extract of water hyacinth (Eichhornia crassipes). - African Journal of Plant Science and Biotechnology 1(1): 40- 42.

[44] Omtvedt, I. T. (1984): A Descriptive Guide for Major Nebraska Thistles. - Agricultural Experimental Station, University of Nebraska, Lincoln, Lincoln, NB.

[45] Putnam, A. R. (1988): Allelochemicals from plants as herbicide. - Weed Technology 2(4): 510-518.

[46] Qureshi, H., Arshad, M., Bibi, Y. (2014): Invasive flora of Pakistan: a critical analysis. Journal of Biodiversity and Environmental Sciences 4(1): 407-424.

[47] Rice, E. L. (1984): Allelopathy (2nd ed.). - Academic Press, Orlando, Florida, USA.

[48] Roseboro, K. (2006): The organic food handbook: a consumer's guide to buying and eating organic food. - Basic Health Publications, Laguna Beach, CA, p. 9. 
[49] Shibu, J., Andrew, R. G. (1998): Allelopathy in black walnut (Juglans nigra L.) alley cropping. II. Effects of juglone on hydroponically grown corn (Zea mays L.) and soybean (Glycine max L. Merr.) growth and physiology. - Plant and Soil 203(2):199-205.

[50] Shimi, P., Poorazar, R., Jamali, M. Bagherani-Torshiz, N. (2006): Evaluating clopyralid as a broad leaf herbicide in canola fields of Iran. - Pakistan Journal of Weed Science Research 12(4): 307-311.

[51] Sodaeizadehet, H., Rafieiolhossaini, M., Havlik, J., Van Damme, P. (2009): Allelopathic activity of different parts of Peganum harmala $\mathrm{L}$ and identification of their growth inhibitors substances. - Journal of Plant Growth Regulation 59(3): 227-236.

[52] Shanab, S. M. M., Shalaby, E. A., Lightfoot, D. A., El-Shemy, H. A. (2010): Allelopathic effects of water hyacinth (Eichhornia crassipes). - Plus One 5(10):1-8.

[53] Sculthorpe, C. D. (1967): The biology of aquatic vascular plants. - Edward Arnold, London.

[54] Xuan, T. D., Shinkichia, T., Khanh., T. D., Chung, M. (2005): Biological control of weeds and plant pathogens in paddy rice by exploiting plant allelopathy: an overview. Crop Protection 24(3): 197-206.

[55] Young, J. A., Evans, R. A. Hawkes, R. B. (1978): Milk thistle (Silybum marianum) seed germination. - Weed Science 26(4): 395-398. 